\title{
A new catalyst for aldol condensation reactions
}

\author{
Yusuf Hassan $^{a}$, Rosa Klein ${ }^{b}$, Perry T. Kaye \\ ${ }^{a}$ Department of Chemistry, Umaru Musa Yar'adua University, Katsina, Nigeria \\ ${ }^{b}$ Department of Chemistry, Rhodes University, Grahamstown, South Africa \\ yusuf.hassan@umyu.edu.ng
}

\begin{abstract}
A new manganese complex was synthesised incorporating 1,2-diaminobenzene linked ketopinic acid scaffold, and successfully utilised as catalyst in the aldol condensation reactions of benzaldehyde with various aliphatic ketones to obtain products with excellent yield of $>99 \%$.
\end{abstract}

Keywords: Lewis acid, manganese, 1,2-diaminobenzene, catalysis, aldol condensation

\section{Introduction}

Aldol condensation reaction as $\mathrm{C}-\mathrm{C}$ bond formation reaction continued to provide opportunity for the synthesis of valuable intermediates, natural products, as well as other biologically important compounds (Vashchenko, 2007; Badia, 2004; Heathcock, 1971). One major concern with some of the reported methodologies has always been the issue of atom economy (Masaharu, 2015; Ziua, 2008). Although number of attempts which employ catalysts was made to improve the condition, it however usually incorporates the use of harsh temperature (Kottapalli, 1998; Climent, 1995; Tichit, 1995; Corma, 1991; Corma, 1990). In this work, a new organic-metal complex based on ketopinic acid scaffold and manganese was constructed and tested as catalyst in the aldol condensation of various aliphatic substrates at a mild temperature.

\section{Experimental}

Reagent-grade ethanol was used as received from commercial source, tetrahydrofuran was distilled from benzophenone/ketyl solutions and chloroform was purified by passing through a column of basic alumina. Analytical thin-layer chromatography was performed on ALUGRAM XTRA silica gel $0.2 \mathrm{~mm}$ (containing a fluorescent indicator at $254 \mathrm{~nm}$ ). Flash chromatography was performed on MN Kieselgel 60 0.063-0.2 mm/70-230 mesh. All other reagents were purchased from Aldrich and used as received. All NMR spectra were recorded on Bruker Avance III HD spectrometer (400 and $600 \mathrm{MHz}$ ). All signals were expressed as ppm down field from TMS, referenced to the residual protonated solvent signals in ${ }^{1} \mathrm{H}$ NMR (7.26 ppm) and to the deuterated carbon signals in ${ }^{13} \mathrm{C}$ NMR (77.36 ppm). IR spectral measurements were carried out on a Perkin Elmer spectrum 400 spectrometer
(ATR). Elemental analyses were conducted using an Elementar Vario micro cube. Melting points were determined by means of a Reichert apparatus and are uncorrected.

\section{2,2'-[1,2-phenylenebis(azan-1-yl-1-ylidene)]bis (7, 7-}

dimethylbicyclo[2.2.1]heptane-1-carboxylic acid) 3

Ketopinic acid (382 mg, $2.096 \mathrm{mmol}$ ) was dissolved in $\mathrm{CHCl}_{3}(5 \mathrm{~mL})$ and 1,2-diaminobenzene (114 mg, $1.048 \mathrm{mmol})$, acetic acid $(0.1 \mathrm{~mL})$ were added successively at room temperature. After $36 \mathrm{~h}$ of reflux, a dark-pink solid precipitated out which was purified by trituration in chloroform to afford the product as a pale pink solid $(0.97 \mathrm{~g}, 90 \%)$, m.p. $162-168^{\circ} \mathrm{C} ; \delta_{\mathrm{H}}$ (400 MHz; CD $\mathrm{CDD}_{3} 0.78(\mathrm{~s}, 3 \mathrm{H}), 0.99(\mathrm{~s}, 3 \mathrm{H}), 1.02$ (s, $3 \mathrm{H}), 1.13(\mathrm{~s}, 3 \mathrm{H}), 1.45-1.46(\mathrm{~m}, 2 \mathrm{H}), 1.71-1.82(\mathrm{~m}$, $6 \mathrm{H}), 2.08-2.10(\mathrm{~m}, 2 \mathrm{H}), 2.26-2.27(\mathrm{~m}, 2 \mathrm{H}), 2.49-$ $2.66(\mathrm{~m}, 4 \mathrm{H}), 2.97-2.99(\mathrm{~m}, 2 \mathrm{H}), 7.20(\mathrm{~s}, 2 \mathrm{H}), 7.47(\mathrm{~s}$, $2 \mathrm{H}) ; \delta_{\mathrm{C}}\left(100 \mathrm{MHz} ; \mathrm{CD}_{3} \mathrm{OD}\right) 16.9\left(\mathrm{CH}_{3}\right), 24.6\left(\mathrm{CH}_{3}\right)$, $24.6\left(\mathrm{CH}_{3}\right), 24.8\left(\mathrm{CH}_{3}\right), 26.6,27.0\left(\mathrm{C} 7,7^{\prime}\right), 29.1$, 30.0 (C5,5'), 30.2, 30.7 (C4,4'), 45.1, 45.2 (C3,3'), 51.5 (C6,6'), 56.4, 56.6 (C1,1'), 115.2 (C13,13'), 123.9, 124.0 (C12,12'), 138.1, 138.2 (C11,11'), 156.2, 156.4 (C2,2'), 177.5, 179.2 (C10,10'). IR (neat, $\mathrm{cm}^{-1}$ ) 2962, 2443, 2013, 1760, 1554. Anal. Calcd for $\mathrm{C}_{26} \mathrm{H}_{32} \mathrm{~N}_{2} \mathrm{O}_{4}$ \%: C, 71.53; H, 7.39; N, 6.42. Found: C, 71.54; H, 7.42; N, 6.43.

\section{2,2'-(1,2-phenylenebis(azan-1-yl-1-ylidene)) bis (7, 7-dimethylbicyclo[2.2.1]heptane-1-carboxylato manganese (III) chloride 4}

Solution of ligand $3(117 \mathrm{mg}, 0.268 \mathrm{mmol})$ and $\mathrm{KOH}(0.5 \mathrm{M}, 8 \mathrm{~mL})$ in ethanol were allowed to reflux with $\mathrm{Mn}(\mathrm{OAc})_{2} \cdot 4 \mathrm{H}_{2} \mathrm{O}(138 \mathrm{mg}, 0.563 \mathrm{mmol})$ under nitrogen atmosphere for $12 \mathrm{~h}$. The reaction mixture was then cooled to room temperature and then brine $(8 \mathrm{~mL})$ was added to give a biphasic solution which was later filtered and concentrated in vacuo. The residue obtained was redissolved in dichloromethane and removed the aqueous 
layer using separating funnel. After concentrating the organic layer, the resulting complex was recrystallized from acetonitrile to furnish a brown amorphous powder (77 mg, $55 \%$ yield). Calculated for $\mathrm{C}_{26} \mathrm{H}_{30} \mathrm{ClMnN}_{2} \mathrm{O}_{4}$ : C, 61.38: H, 7.55: N, 4.77. Found: C, 60.75: H, 8.51: N, 4.79 IR (neat, $\mathrm{cm}^{-1}$ ): $1740(\mathrm{C}=\mathrm{O}), 1689(\mathrm{C}=\mathrm{N})$.

\section{Typical procedure for the aldol condensation reactions}

Potassium hexamethyldisilazide (KHMDS, $43.2 \mu \mathrm{l}$, $0.0216 \mathrm{mmol}, 0.5 \mathrm{M}$ in toluene) and a solution of water $(48 \mu \mathrm{l}, 0.048 \mathrm{mmol}, 1 \mathrm{M}$ in THF) were vigorously stirred for $20 \mathrm{~min}$. This was followed with the addition of ketone $(15 \mathrm{mmol})$ and further stirring for additional $10 \mathrm{~min}$. To the resulting solution, catalyst 4 (79 mg, 10 mole \%) and aldehyde $(1.5 \mathrm{mmol})$ in THF $(0.5 \mathrm{~mL})$ were added. The mixture was continuously stirred with regular monitoring by ${ }^{1} \mathrm{H}$ NMR.

\section{(Z)-2-benzylidenecyclohexanone 7}

Yellow oil; $>99 \%$ yield, $\delta_{\mathrm{H}}\left(600 \mathrm{MHz} ; \mathrm{CDCl}_{3}\right)$ $1.50\left(\mathrm{q}, J=2.0 \mathrm{~Hz}, \mathrm{CH}_{2}\right.$ ), 1.55 (q, $J=2.3 \mathrm{~Hz}, \mathrm{CH}_{2}$ ), $1.57\left(\mathrm{t}, J=3.1 \mathrm{~Hz}, \mathrm{CH}_{2}\right), 1.63\left(\mathrm{t}, J=3.1 \mathrm{~Hz}, \mathrm{CH}_{2}\right)$, $6.88(\mathrm{~s}, 2 \mathrm{H}), 7.32-7.33(\mathrm{~m}, 2 \mathrm{H}), 7.40(\mathrm{~s}, 1 \mathrm{H}), 7.61(\mathrm{~s}$, $1 \mathrm{H}), \delta_{\mathrm{C}}\left(100 \mathrm{MHz} ; \mathrm{CDCl}_{3}\right) 22.2\left(2 \times \mathrm{CH}_{2}\right), 24.3\left(\mathrm{CH}_{2}\right)$, $35.0 \quad\left(\mathrm{CH}_{2}\right), \quad 128.2 \quad(2 \times \mathrm{ArC}), \quad 128.3 \quad(2 \times \mathrm{ArC})$, $128.4(\mathrm{ArC}), 133.1(\mathrm{ArC}), 134.0(\mathrm{CH}), 139.5(\mathrm{C})$, $198.3(\mathrm{C}=\mathrm{O})$. IR (neat, $\left.\mathrm{cm}^{-1}\right) 3038,1671,1638$, 1450 .

\section{(E)-2-benzylidene-6-methylcyclohexanone $9 \mathbf{a}$}

Yellow oil; >99\% yield; $\delta_{\mathrm{H}}\left(600 \mathrm{MHz} ; \mathrm{CDCl}_{3}\right) 1.22(\mathrm{~d}$, $\left.J=1.2 \mathrm{~Hz}, \mathrm{CH}_{3}\right), 1.23-1.24(\mathrm{~m}, 2 \mathrm{H}), 1.32-1.36(\mathrm{~m}$, 2H), 2.10-2.12 (m, 2H), 2.22-2.32 (m, 2H), 6.89 (s, 2H), 7.41-7.43 (m, 2H), 7.54 (s, 1H), 7.81 (s, 1H). $\delta_{\mathrm{C}}\left(100 \mathrm{MHz} ; \mathrm{CDCl}_{3}\right) 16.2\left(\mathrm{CH}_{3}\right), 26.3\left(\mathrm{CH}_{2}\right)$, $29.2\left(\mathrm{CH}_{2}\right), 30.6\left(\mathrm{CH}_{2}\right), 40.6\left(C-\mathrm{CH}_{3}\right), 133.2(2 \times \mathrm{ArC})$, $136.3(2 \times \operatorname{ArC}), 136.7(\operatorname{ArC}), 134.2(\mathrm{CH}), 134.8(\operatorname{ArC})$, $140.1(\mathrm{C}), 199.3(\mathrm{C}=\mathrm{O})$. IR (neat, $\left.\mathrm{cm}^{-1}\right)$ 3045, 1674, $1632,1447$.

\section{(E)-2-benzylidene-4-methylcyclohexanone $\mathbf{9 b}$}

Yellow oil; >99\% yield, $\delta_{\mathrm{H}}\left(600 \mathrm{MHz} ; \mathrm{CDCl}_{3}\right) 0.99(\mathrm{~d}$, $\left.J=0.5 \mathrm{~Hz}, \mathrm{CH}_{3}\right), 1.62-1.68(\mathrm{~m}, 2 \mathrm{H}), 1.85-1.93(\mathrm{~m}$, $2 \mathrm{H}), 2.33-2.80(\mathrm{~m}, 2 \mathrm{H}), 2.86-2.93(\mathrm{~m}, 1 \mathrm{H})$, 3.20-3.52 (m, 1H), 3.62-3.72 (m, 1H), $7.02(\mathrm{~s}$, $\mathrm{CH}), 7.61-7.68(\mathrm{~m}, 2 \mathrm{H}), 7.72(\mathrm{~s}, 1 \mathrm{H}), 7.84(\mathrm{~s}$, $1 \mathrm{H}) . \delta_{\mathrm{C}}\left(100 \mathrm{MHz} ; \mathrm{CDCl}_{3}\right) 16.2\left(\mathrm{CH}_{3}\right), 26.3\left(\mathrm{CH}_{2}\right)$, $29.2\left(\mathrm{CH}_{2}\right), 30.6\left(\mathrm{CH}_{2}\right), 40.3\left(\mathrm{C}-\mathrm{CH}_{3}\right), 133.2(2 \times \mathrm{ArC})$, 136.3 (2×ArC), 136.7 ( $\operatorname{ArC}), 134.2(\mathrm{CH}), 134.8(\operatorname{ArC})$, $140.1(\mathrm{C}), 199.5(\mathrm{C}=\mathrm{O})$. IR (neat, $\left.\mathrm{cm}^{-1}\right)$ 3044, 1675, $1632,1447$.

\section{Trans-1-phenylhept-1-en-3-one $\mathbf{9 c}$}

Yellow oil; >99\% yield, $\delta_{\mathrm{H}}\left(600 \mathrm{MHz} ; \mathrm{CDCl}_{3}\right)$ $0.96(\mathrm{t}, J=0.9 \mathrm{~Hz}, 3 \mathrm{H}), 1.52-1.59(\mathrm{~m}, 4 \mathrm{H}), 3.20(\mathrm{t}$, $J=3.1 \mathrm{~Hz}, 2 \mathrm{H}), 6.53(\mathrm{~d}, J=12.0 \mathrm{~Hz}, 1 \mathrm{H}), 6.66(\mathrm{~d}$, $J=12.0 \mathrm{~Hz}, 1 \mathrm{H}), 6.83(\mathrm{~d}, J=6.5,2 \mathrm{H}), 7.66-7.68(\mathrm{~m}$, $3 \mathrm{H}) . \delta_{\mathrm{C}}\left(100 \mathrm{MHz} ; \mathrm{CDCl}_{3}\right) 12.3\left(\mathrm{CH}_{3}\right), 23.4\left(\mathrm{CH}_{2}\right)$, $28.6\left(\mathrm{CH}_{2}\right), 40.2\left(\mathrm{CH}_{2}\right), 128.3(\mathrm{CH}), 129.0(2 \times \mathrm{ArC})$, $131.1(2 \times \operatorname{Ar} C), 135.1(\operatorname{ArC}), 140.1(\operatorname{ArC}), 147.2(\mathrm{CH})$, $199.5(\mathrm{C}=\mathrm{O})$. IR (neat, $\left.\mathrm{cm}^{-1}\right)$ 3051, 1668, 1646, 1510 .

\section{Cis-4,4-dimethyl-1-phenylpent-1-en-3-one $9 d$}

Yellow oil; >99 \% yield, $\delta_{\mathrm{H}}\left(600 \mathrm{MHz} ; \mathrm{CDCl}_{3}\right) 1.51(\mathrm{~s}$, $9 \mathrm{H}), 6.93(\mathrm{~d}, J=6.0 \mathrm{~Hz}, 1 \mathrm{H}), 7.43(\mathrm{~d}, J=6.0 \mathrm{~Hz}, 1 \mathrm{H})$, $7.66-7.68(\mathrm{~m}, 2 \mathrm{H}), 7.72-7.75(\mathrm{~m}, 3 \mathrm{H}) . \delta_{\mathrm{C}}(100 \mathrm{MHz}$; $\left.\mathrm{CDCl}_{3}\right) 33.2\left(\mathrm{CH}_{3}\right)_{3} 43.1\left[\mathrm{C}\left(\mathrm{CH}_{3}\right)_{3}\right], 127.3(\mathrm{CH})$, $129.1(2 \times \operatorname{Ar} C), \quad 129.8(2 \times \operatorname{ArC}), 133.10 \quad(\operatorname{Ar} C)$, $138.0(\operatorname{ArC}), 140.2(\mathrm{CH}), 198.5(\mathrm{C}=\mathrm{O})$. IR (neat, $\left.\mathrm{cm}^{-1}\right) 3055,1671,1644,1525$.

\section{Results and Discussion}

The ligand 3 reported by Yang 2003 was synthesised using the standard procedure, followed by the complexation step (Scheme 1) to obtain the new Mn(III) complex 4 (Kureshy 1997). Thus, the synthesis was carried out by refluxing ketopinic acid $\mathbf{1}$ with the 1,2-diaminobenzene $\mathbf{2}$ and a catalytic amount of glacial acetic acid, using chloroform as solvent (Scheme 1). Condensation of ketopinic acid

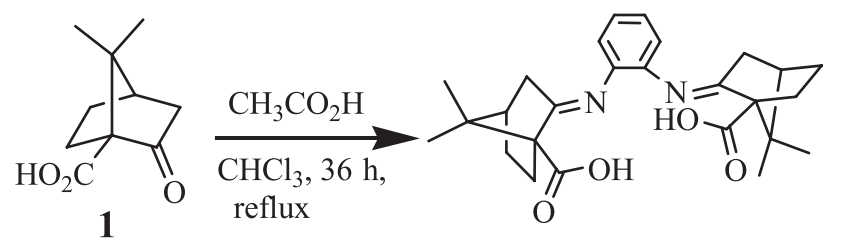

3

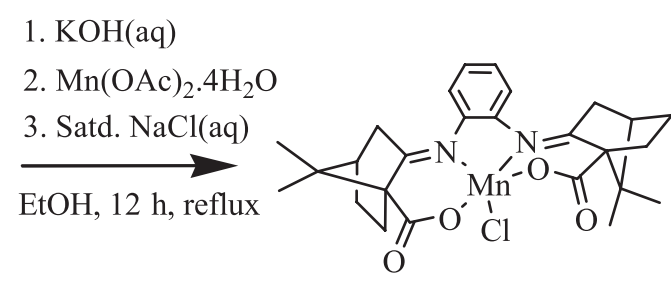

4<smiles>Nc1ccccc1N</smiles>

Scheme 1. Synthesis of ketopinic acid-derived complex. 
(2 equiv.), with the 1,2-diaminobenzene as a linker enabled the generation of the C-2 symmetry and expand the space occupied by the ligand on each face of the final complex. It was hoped that the position of the manganese atom tightly situated at the centre of the ketopinic acid moieties would enhance the coordination of the electrophilic centres of the substrates in the course of the reaction.

The catalytic acitivity of complex $\mathbf{4}$ was investigated following the procedure reported by Yoshikawa 1999 with modification. Hence benzaldehyde was reacted with cyclohexanone in different ethereal solvents and at three catalyst loadings (Table 1). The results shows that THF is the most efficient solvent as it allows the formation of the aldol product in $>99 \%$ yield at relatively shorter time. Attempt to reduce the catalyst loading result in longer duration of the reaction. Although not given in Table 1, but the method development reveals that any attempt to reduce the cyclohexanone equivalent furnish the corresponding aldol in negligible amount. In fact it could only be detected in the ${ }^{1} \mathrm{H}$ NMR spectroscopic analysis of the crude mixture.

Based on the catalyst performance, other substrates were explored to further ascertain its efficacy. The results (Table 2) demonstrate that the catalyst has relatively wide spectrum of activity.

\section{Conclusions}

Ketopinic acid was successfully employed as a scaffold in the synthesis of a manganese (III) complex.
The complex thus obtained was used in the aldol condensation reactions of benzaldehyde with various aliphatic ketones. Interestingly it was found that irrespective of the structure of the aliphatic ketone, the yield of the products was apparently excellent in less than an hour.

\section{Acknowledgements}

The financial support of the National Research Foundation and the Tertiary Education Trust Fund, Nigeria for granting fellowship to Yusuf Hassan is gratefully acknowledged.

\section{References}

Badía C, Castro JM, Linares-Palomino PJ, Salido S, Altarejos J, Nogueras M, Sánchez A (2004) Molbank 1: M388.

Climent MJ, Corma A, Iborra S, Primo JJ (1995) Catal. 151: 60-66.

Corma A, Martin-Aranda RM (1991) J. Catal. 130: 1130-1137.

Corma A, Fornes V, Martin-Aranda RM, Garcia H, Primo JJ (1990) Appl. Catal. 59: 237-248.

Heathcock CH, Ellis JE, McMurry JE, Coppolino A (1971) Tetrahedron Lett. 12: 4995-4996.

Kureshy RI, Khan N, Abdi S, Iyer P, Bhatt A (1997) J. Mol. Cat. A: Chemical 120: 101-108.

Kottapalli KR, Monique GJ, Sanchez V, Francois F (1998) J. Catal. 173: 115-121.

Masaharu S, Yasuhiko A, Makoto NJ (2015) Org. Chem. 80: 8830-8835.

Tichit D, Lhouty MH, Guida A, Chiche BH, Figueras F, Auroux A, Bartalini D, Garrone EJ (1995) Catal. 151: $50-59$.

Tab. 1. Aldol condensation of benzaldehyde with cyclohexanone in three different solvents in the presence of complex $4^{\mathrm{a}}$.

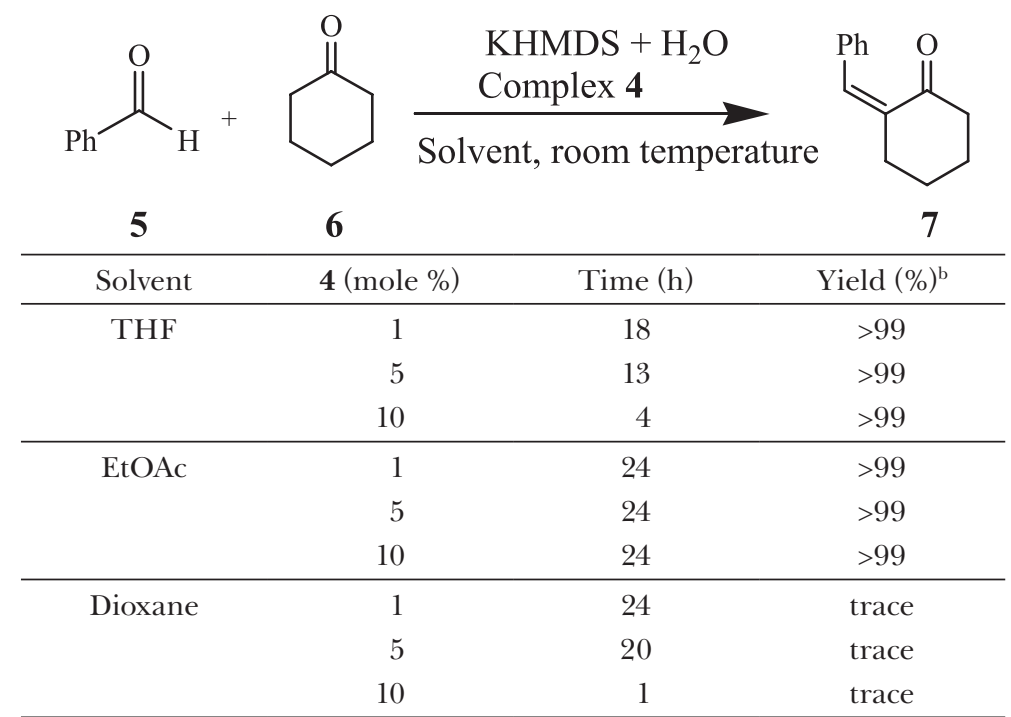

${ }^{\text {a} B e n z a l d e h y d e ~}(1.5 \mathrm{mmol})$, cyclohexanone $(15 \mathrm{mmol})$. Cis assignment for 7 was determined using DFT calculation of the lowest-energy isomer.

${ }^{b}$ Determined by ${ }^{1} \mathrm{H}$ NMR spectroscopic analysis of the reaction mixture. 
Tab. 2. Aldol condensation of various aliphatic substrates in the presence of $\mathbf{4}(10 \text { mole } \%)^{1}$

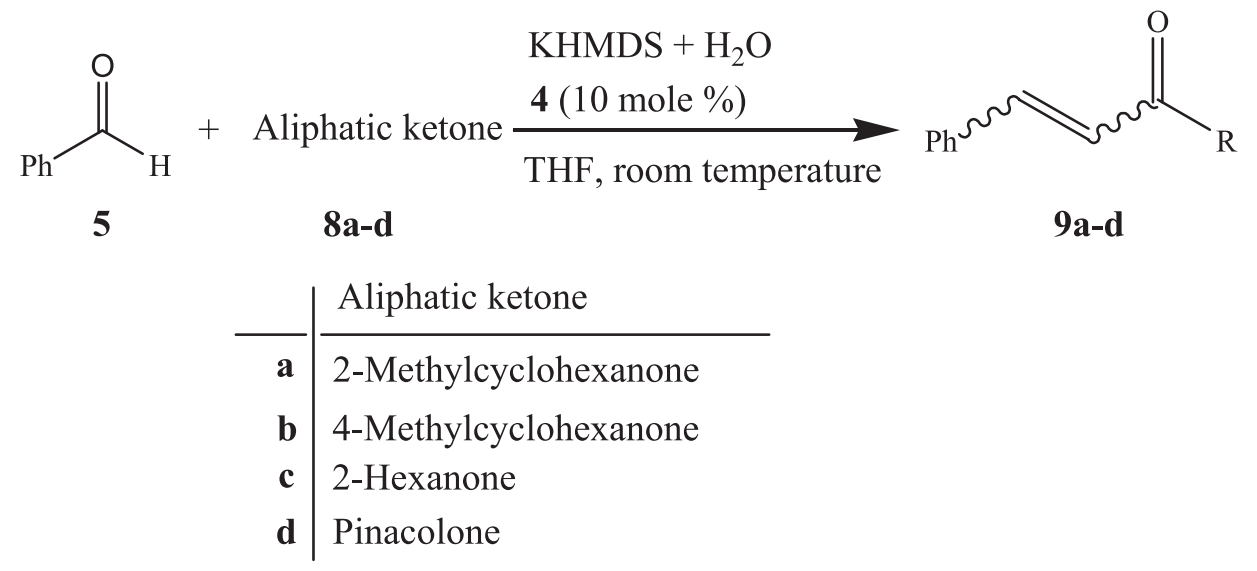

\begin{tabular}{lll}
\hline Aldol product, 9 & Time (mins) & Yield (\%) ${ }^{2}$ \\
\hline
\end{tabular}

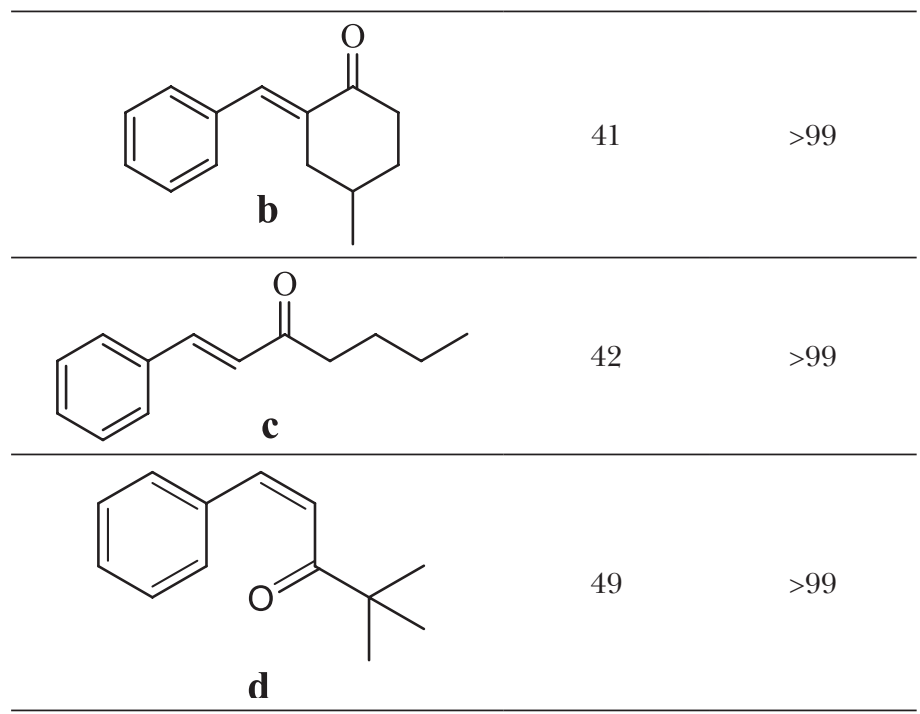

${ }^{1}$ Benzaldehyde ( $\left.1.5 \mathrm{mmol}\right)$, Ketone $(15 \mathrm{mmol})$. Geometrical assignment for $\mathbf{9 a}$ and $\mathbf{9 b}$ was determined using DFT calculation of the lowest energy isomers.

${ }^{2}$ Determined by the analysis of the reaction mixture using ${ }^{1} \mathrm{H}$ NMR spectroscopy.

Vashchenko V, Kutulya L, Krivoshey A (2007) Synthesis 38: 2125-2134.

Yang K-S, Lee W-D, Pan J-F, Chen KJ (2003) Org. Chem. 68: 915-919.
Yoshikawa N, Yamada YM, Das J, Sasai H, Shibasaki M (1999) J. Am. Chem. Soc. 121: 4168-4178.

Ziua W, Guodong Y, Jing Q, Meng G, Liping C, Anxin W (2008) Synthesis 22: 3675-3681. 